\title{
A Projection of Halal Tourism: A Case Study of Pekalongan City, Indonesia
}

\author{
K Ismanto ${ }^{1}$ \\ Faculty of Economy and Islamic Bussiness, IAIN Pekalongan ${ }^{1}$ \\ $\left\{\right.$ kuat.ismanto@iainpekalongan.ac.id $\left.{ }^{1}\right\}$
}

\begin{abstract}
The purpose of this study is to explore the projection of halal tourism development in Pekalongan City. By using a qualitative approach, this research collects data with observation of the tourism spot, interview with the government and tourism agents, and documentation. The results of this study reveals several facts. First, Pekalongan has complete tourism spots for the past and present time, including shopping center, culture, religious destination, culinary, natural scenery, and special events. Batik, as a distinctive product of Pekalongan, along with its derivatives become a leading tourist attraction. The various nicknames for Pekalongan, such as a creative city, suggest a potential to support this city in realizing halal tourism. Second, halal tourism in Pekalongan still needs support, including (1) contribution from the city government in issuing policies supporting halal tourism, in the forms of local regulations, organizing exhibitions, and others (2) adequate transportation, which has not been optimized. (3) sufficient religious facilities, which needs to be revitalized. (4) the need of increasing the numbers of sharia hotels (5) educated community in realizing halal tourism (6) the improved support of the entrepreneurs of creative industries. Third, to meet the Global Muslim Travel Index, there must be developing infrastructure, supported by the serious efforts from the government, tourists, and also the community. The government's serious efforts in developing the halal tourism will have an impact on government revenue, job opportunity, and public welfare, particularly for the tourism actors.
\end{abstract}

Keywords: Halal Tourism, Pakalongan, infrastructure

\section{Introduction}

Halal tourism has become a new business trend and a common topic around the world since the 1980s [1]. This trend develops not only in Muslim-majority but also in Muslimminority countries, such as Thailand [2] and Singapore [3]. Malaysia, Thailand, Singapore, and South Korea have utilized the halal tourism (industry) trend as the main pillar of their national tourism growth [4]. As the largest Muslim-majority country in the world, Indonesia takes this opportunity. Even, in its development, Indonesia has achieved several international awards related to halal tourism [5]. For this achievement, the Indonesian government becomes more serious in developing the halal tourism.

There are several terms used to call halal tourism, including halal tourism, Islamic tourism, sharia travel [6] and Muslim-friendly tourism. In line with those terms, there is no single definition of halal tourism besides the similarity in their concepts. Based on the concept, halal tourism is a tourism concept considering the Muslim's basic values in servicing the 
customers, which covers accommodations, restaurants, and Islamic values-based tourism activities [7]. The concept of halal tourism is the actualization of the Islamic concept which emphasizes halal and haram as the main benchmarks. It means that all aspects of tourism activities are inseparable from halal certification, which is a required reference for every tourism actor [8]. This halal tourism covers all aspects of tourism in general, although there is a requirement demanding everything must be based on of sharia principles. For example, this tourism aims to improve spirituality, along with the target of fulfilling desires and pleasures as well as fostering religious awareness [9].

Pekalongan, a city in Central Java, has a number of nicknames, including batik city, world's creative city, world's city of batik, healthy city, minapolitan city, and trading city [10]. The city, which is located on the northern coastline, connects the East Java and West Java as well as other large cities and has a strategic position on various aspects. Various forms of infrastructure such as highways, train stations, and the development of the surrounding area are supporting factors for city development. In addition, Pekalongan was classified as one of the UNESCO creative cities in the crafts \& folk art category in December 2014 and rewarded the "World's City of Batik" brand.

There are various and complete tourist destination in Pekalongan, but they have not quite encouraged the numbers of tourist visits, especially those from foreign countries. From January to March 2019, there were only about 60 foreign tourists visited Pekalongan [11] which did not evenly visit all of the tourism destinations. They only focused on only a limited objects, which is especially related to batik.

One of the purposes in realizing halal tourism destination is to increase the number of local and foreign tourist visits. The increasing tourist numbers will automatically increase regional and community income. Subarkah [12] stated that diplomacy through halal tourism is able to attract foreign tourists and investment. For an instance, when Lombok was declared a halal tourist destination and it received awards, there was increasing numbers of tourist arrivals [13].

Kusumanto [14] explained there are five important aspects in the development of halal tourism, namely products, services, infrastructure, government support, and human capital resources. Halal tourism principles have been summarized by Henderson [15]; [7];[16] which cover: halal food, no alcohol, no pork, no discotheques, male staff for male guests, female staff for female guests, appropriate entertainment, gender-separated prayer rooms (mosques or mushallas), Islamic clothing for staff uniforms, the availability of the Quran and prayer equipment in the rooms, qibla direction, no human art, toilets are not faced the qibla, Islamic finance, and hotels or other tourism companies must be based on Islamic principles. This paper explores the projected development of halal tourism in Pekalongan City which refers to the halal tourism ecosystem. The study began with a description of the realization of halal tourism and supporting factors as an effort to realize it. After that the development of halal tourism was reviewed in terms of the Global Muslim Travel Index [17].

\section{Method}

This research is categorized as a field research using qualitative approach. Cresswell [18] said that qualitative research is an inquiry process to understand social or human problems based on the creation of a complete holistic depiction in the form of words. This case study choses Pekalongan as the setting since this city is located in Central Java which was designated as one of the halal tourist destinations by the Indonesian Ministry of Tourism and 
Culture. According to Yin [19], a case study is used to probe issues and explore further how those issues take place.

Primary data were obtained directly from the Department of Tourism in Pekalongan and tourism actors through observation, interviews, and documentation. Secondary data were regulations and documents, media reports, and the other relevant sources. The data were analyzed using content analysis.Payne and Payne [20] stated that this analysis interprets meaning from written or visual data by allocating their content to the predetermined categories in detailed, which then measure and interpret the results.

\section{Results and Discussion}

\section{Conditions and Development of Tourism Industry}

Pekalongan City is not a large area, and it is only divided into 4 (four) sub-districts and 27 villages. This area covers $45.25 \mathrm{KM}^{2}$ or about $0.14 \%$ of the total area of Central Java. Islam is the major religion in Pekalongan City, along with the other religions including Christianity, Catholicism, Hinduism, Buddhism, and Confucianism. Thus, this city is called as not only a plural city but also a religious city. The plurality of Pekalongan is illustrated by the existing multiethnic community. In addition to the Javanese tribe, Tioghoa people in Chinatown and Arab communities in Klego Arab village also live well in this city. The religiosity appears in religious activities organized by ulama live in Pekalongan, which can be a gathering event of tarekat experts (Islamic scholars) from around the world. There are also 44 boarding schools with 4,706 students and 158 mosques scattered in four districts.

Pekalongan has a number of attractions which are classified into several types, including cultural tourism, shopping, nature, religious, culinary, and event tourism. Basically, all the types of tourism are developed by the Pekalongan government, but batik and its derivatives take place as an excellent tourism in this city. The following table shows types and forms of tourism industry in Pekalongan City.

\begin{tabular}{|c|c|}
\hline $\begin{array}{c}\text { Types of } \\
\text { Tourism Industry } \\
\end{array}$ & $\begin{array}{cc}\begin{array}{c}\text { Forms of } \\
\text { Tourism Industry }\end{array} \\
\end{array}$ \\
\hline Cultural Tourism & $\begin{array}{l}\text { Museum Batik (Batik Museum) } \\
\text { Kawasan Kota Tua Jetayu(Jetayu Old Town) } \\
\text { Syawalan (Giant Lopis) } \\
\text { Sedekah Laut } \\
\text { Nyadran, Pek Cun } \\
\text { Pawai Cap Gomeh } \\
\text { Sintren } \\
\text { Simthuddurror } \\
\text { Samproh } \\
\text { Sufi Multikultur } \\
\text { Kuntulan } \\
\text { Barongsay \& Liong }\end{array}$ \\
\hline Shopping Tourism & $\begin{array}{l}\text { Sentra ATBM Medono (Medono Woven Center) } \\
\text { Pasar Grosir Batik Setono (Batik Wholesale Market) } \\
\text { Mall (Matahari Hypermart, Ramayana, Transmart) } \\
\text { Kampung Batik Kauman (Kauman Batik Village) } \\
\text { Kampung Wisata Batik Pesindon (Pesindon Batik Village) } \\
\text { Pasar Grosir Gamer (Gamer Wholesale Market) }\end{array}$ \\
\hline
\end{tabular}




\begin{tabular}{ll}
\hline \multirow{3}{*}{ Nature Tourism } & Pasar Grosir MM (MM Wholesale Market) \\
& Pantai Pasir Kencana (Pasir Kencana Beach) \\
& Pantai Slamaran Indah (Slamaran Indah Beach) \\
& Pekalongan Mangrove Park \\
& Wisata Bahari (PPNP) \\
& Ziarah (visiting) /Khaul(commemorating) Makam Habib Ahmad Bin Tholib \\
Religious Tourism & Al Atas \\
& Makam Pangeran Sampang Tigo (Pandito Banyu Segoro) \\
& Soto Tauto \\
Culinary Tourism & Garangasem \\
& Megono \\
& Gulai Kacang Ijo \\
& Kopi Tahlil \\
& Nasi Kebuli \\
& Pekan Batik Pekalongan (Pekalongan Batik Week) \\
& Tradisi Syawalan \\
& Khaul (Commemorating) Habib Ahmad Bin Thalib Al-Athas \\
& Pameran Kreatifitas dan Inovasi (Creativity and Innovation Exhibition) \\
Event Tourism & Festifal Karnaval Kostum Batik (Batik Parade) \\
& Pawai Cap Gomeh \\
& Nyadran \\
& Tradisi Pek Cun \\
& Jatayu Car Free Night \\
& Kauman Art Batik Festival \\
& Peringatan Hari Batik Nasional (National Batik Day) \\
& \\
& \\
&
\end{tabular}

Source: Pekalongan Culture and Tourism Department 2019.

Batik is a cultural tourism that is most easily found in Pekalongan.It represents the most distinctive Pekalongan culture and the history can be seen in the Museum Batik Pekalongan (Pekalongan Batik Museum). This museum does not only store the collection of Pekalongan batik heritage, but also the collection of various batik motifs from various regions in Indonesia. By June 2019, the batik museum has been visited by 84 foreigners and 13,996 local tourists contributing Rp. 48,575,000.

The most famous shopping tourism in Pekalongan is batik products besides sarong. Various batik are available in various places, including Medono ATBM Center, Setono Batik Wholesale Market, Kauman Batik Village, and Pesindon Batik Tourism Village. The products are easily found in boutiques, malls, and modern shopping centers. In addition to batik centers, there is a number of shopping tourism managed by private parties, such as batik shops and boutiques spread around the city. The available products do not only in the form of hand painted and stamped batik, but also printed batik. The city government's strategy by opening the route of a highway exit directly to the Setono wholesale market seems to be the supporting effort in attracting tourists to buy batik at the shopping center. Instead of batik, this city is also known as a producer of distinctive woven and batik sarong. Pekalongan woven sarong has been promoted in foreign countries. To support this product, the Mayor has instructed the government employees to wear it at certain events.

Pekalongan culinary tourism products include nasi megono (megono rice), soto tauto, and nasi kebuli (kebuli rice). Megono rice can be found in various restaurants, food stalls, even small stalls in the center of the crowd, like the city square. Soto tauto is a immensely wellknown culinary product in Pekalongan, which is named referring to the name of the restaurant owner. Besides those two kinds of culnary, there are kebuli rice that is served in certain restaurants around the city center. Megono rice are sold in the morning or evening in the 
people's stalls around the downtown, including the city square. These three types of special foods become the parts of the five-star hotels and malls' menu. However, the city government has not determined the serving standard or halal certainty on the food.

This city also develop educational tourism particularly related to batik products. This tourism prioritizes the uniqueness of the processing and producing batik. One of the examples of such tourism is the canting craft tourism, where visitors can see the process of making canting used to coloring batik. Another example is the process of making batik, where visitors can see the how to make hand-written and stamped batik. During this tour, batik communities including Kauman and Pesindon batik villages sought to invite foreign tourists to learn how to make batik at these batik centers.

Geographically, Pekalongan city is in the coastal area of the north coast of Java, enabling this city to provide beaches as the natural attractions. There are a number of beaches managed by the city government, namely Pasir Kencana Beach, Slamaran Beach, and Marine Tourism which are completed with aquariums and a fisheries museum. Pekalongan Mangrove Park has been well managed by the government and it is supported by the adequate facilities. The efforts in improving the facilities are still carried out by the government.

In addition to the tourism above, Pekalongan also develops religious tourism. It is a common thought that Pekalongan culture have a strong relationship with religion, Javanese culture, and people's belief. Islamic cultural tourism comprises Simthuddurror, Samproh, and Sufi Multikultur. Cultural tourism related to Javanese customs includes Sedekah Laut (Nyadran, Pek Cun), Sintren and Kuntulan. The other cultural tourism include Barongsay \& Liong and Cap Gomeh Parade. Syawalan tradition is held a week after Eid al-Fitr, which is located on Jlamprang Street and well-known by the giant lopis cutting with more than 1 ton weight and about 2 meters high.

Most of the Pekalongan people are Muslim, as consequently the Islamic spirit appears everytime and everywhere. The tombs of Pekalongan Islamic figures, such as the tomb in Sapuro, attract the visitors from outside. Khoul is one of the activities carried out in the tomb, in commemoration of the death of Habib Ahmad bin Abdullah bin Talib Alatas. In addition, the existence of islamic leaders, for example Habib Lutfi bin Yahya, is able to promote the religiosity in Pekalongan. The religious leaders along with the series of religious activities frequently become the center of national and international religious activities. For the example, there is a habitual meeting of tarekat leaders coming from throughout the world and it is attended by Islamic figures from 38 countries. This event automatically fosters the economy, such as increasing hotel, restaurants and other income profits.

Beside the tourism above, Pekalongan also serves the interesting events to follow and visit. Those are annual event including Pekan Batik Nusantara/ Nusantara Batik Week (PBN) or International Batik Week / Pekan Batik Internasional (PBI), Celebration of Pekalongan City Anniversary, the parade as well as special arts and cultural show in Pekalongan City, Pintoe Dalam Festival, and Balloon Festival at the week after Eid. These events have attracted the tourists to come and enliven.

Pekalongan Tourism Department also develops special interest in tourism. Some of those are Jetayu Car Free Night, Seketing Festival, modern steel or fiber ship building, traditional wood shipbuilding. Those tours are quite interesting for local tourists. In addition, the old Chinatown is also a distinctive tourist attraction [21]. These special tours have not yet widely known but they are adequately impressive for tourists.

Although Pekalongan has complete and attractive tourist destinations, the city government has not planned to develop halal tourism. In fact, the destinations have met the requirements of halal tourism as stipulated in the MUI DSN fatwa No. 108/DSN-MUI/X/2016. The concept of 
halal in tourism is an inseparable part of the development of Central Java which was established as a halal tourism developing province by the central government. Halal tourism conceived by the Tourism Department is only a small part of the comprehensive Halal tourism concept.

\section{Developing Halal Tourism}

There are five considerable aspects in developing halal tourism, involving products, services, infrastructure, government support, and human resources [14]. These five aspects are the main elements in the halal ecosystem. As a projection, it is necessary to identify the supporting and obstructing factors in developing halal tourism in this city.

Tourism products in Pekolongan are considered to be completed and those which produced by the government and Pekalongan people are very diverse. Batik as the main product is needed by the community, one of which is batik outfit. Woven and batik sarong, male and female muslim clothing are also the dominant products produced by this city. Besides, people this city manufacture crafts made from water hyacinth, banana stem, and pineapple.

Regarding the services for the tourists, Pekalongan provides various lodging and restaurants. There have been three sharia-based hotels which support the realization of halal wisata. Those three hotels are supported by sharia hotels outside Pekalongan located close to the tourist destinations. In addition, there are islamic hospitals completed with supporting facilities, mosques and praying room (Mushola) in every village and around the main road, even there is a historic mosque located in the city center and precisely in the city square namely the Pekalongan Jami’ Mosque.

Lately, the government has promoted the tourism development by issuing supporting several policies. The government, particularly the Department of Tourism, Culture, Youth and Sports compiled a series of tourism promotions. They held various national and international events, some of which are the Fashion Show entitled "Heritage, Culture, and Trend Fashions of the World City of Batik", exhibitions and Pekalongan information week, arts and culture festivals, and lantern competitions in the Jetayu cultural area. Some of those activities are annually held and some of them are only for celebrating certain events at certain times. Pekalongan city also actively participates in out of city exhibitions, such as a joint promotion for celebrating the 44th Anniversary of Taman Mini Indonesia Indah (TMII) Jakarta.

To realize and enhance tourism industry in Pekalongan city, the government established Pekalongan Tourism Promotion Board/ Badan Promosi Pariwisata Kota Pekalongan (BP2KP), Tourist Information Center and website http://tourism.pekalongankota.go.id/. The establishment is a proof of the support from the government for tourism industry. In addition, the board has created websites and social media accounts to promote the industry, one of which is http://tourism.pekalongankota.go.id/.

There are several aspects that must be improved to support halal tourism in Pekalongan. The tidal flood additionally interferes comfort and access to the tourist destination. The crowded traffic in the city center during school and office hours frequently causes discomfort for the tourists. Heavy vehicles, e.g. buses and trucks are still able to access the main road of the city that disturbs the city's transportation comfort and system. The minimal transportation connecting between tourists' destinations demands the city government to solve the problem.

Regarding the historical aspects and the development of halal tourism, it can be assumed that batik tourism, particularly batik preservation, is the tourism industry that can be developed and improved in Pekalongan as the result of batik's role as the distinctive product 
of Pekalongan. Batik tourism and its derivatives emphasize and reaffirm Pekalongan as the creative city, as claimed by UNESCO.

For foreign tourists, Pekalongan geographically cannot be considered as a major tourist destination. It is a common thought that Pekalongan is only the second tourist destination after the major destinations such as Jakarta, Bali, and other big cities. This is the result of the location and minimum infrastructure in Pekalongan, some of which are disability for the international airports and large ports to be visited by cruise ships. The main and convenient mass transportation in Pekalongan are trains and buses.

Excluding the infrastructure problem, the various tourist attractions have not been upheld. The existing tourist destinations, e.g. beaches and local culture, commonly are available in other regions. Religious activities along with religious rituals are not impressive enough for the tourists, especially foreigners. According to Rahmiati, et al. [22]. Islamic values is in position to influence the tourists' satisfaction. This is in line with findings by Isa, Chin, \& Mohammad [23] stated that physical halal and non-physical halal are influential on tourists' satisfaction.

From the description above, it is undeniable that Pekalongan city has complete tourist destinations, including cultural, religious, natural, shopping, culinary, even the supporting events in tourism destinations. The existing tourist destinations are very potential to be developed as halal tourist destinations. Every tourist destination needs adequate worship facilities. Halal restaurants in Pekalongan only needs legal certification. However, the sharia hotels and inns must improve their quality and quantity.

Every government, both at the central and regional levels, must have the desire to advance their regions to obtain local revenue. This income can be optimized to build the area for the sake of society welfare. Nevertheless, several aspects still need to be revitalized to realize halal tourism in Pekalongan. The development of excellent halal tourism in Pekalongan City will promote multiplier effect on other sectors, such as culinary, transportation, souvenirs, job vacancy. However, the intensive training is a necessity for the existing resources and the people to have deep understanding of halal tourism concept then all stakeholders support each other.

\section{The Challenges of Developing Halal Tourism}

In realizing the concept of halal tourism, Pekalongan still faces several challenges. According to the Global Muslim Traveling Index (GMTI) in 2019, there is discussion of halal tourism challenges. GMTI as a measurement has been used by the Indonesian government as a reference in measuring halal tourism standards. The GMTI approach consists of four aspects of assessment, namely access, communication, environment, and service [5].

\section{Access}

The Indonesian government has provided conveniences for foreigners to visit Indonesia. One of them is in the form of visa-free policies for tourists from certain countries. This policy serves benefit for the developing tourism regions. As a consequence of the unavailability of an international airport, the tourists must go to airports located in other cities, such as Semarang and Jakarta. Therefore, they cannot visit Pekalongan directly.

Pekalongan does not have special transportation that can take tourists to visit tourist destinations directly. The crowd, even traffic jams frequently occur at certain times and locations which does not support the development of international tourism. Moreover, this city 
has inadequate public transportation to reach tourist destinations. Fortunately, batik community habitually facilitates the tourists to visit directly to the batik village.

\section{Communication}

The city government has tried to promote Pekalongan tourism through several ways, including websites, social media, and the book "Calendar of Events Kota Pekalongan" in 2019. This book contains a series of events in one year. Various existing media, e.g. exhibitions, websites, social media have already existed, but the content and communicative language should be improved. This city is also lack of tour guides who have competences in speaking foreign language that sometimes demands the tourists to bring their own translators. Absolutely, the use of foreign languages is to facilitate the foreign tourists in understanding the attractions offered and this problem potentially influence the tourists visit.

\section{Environment}

Pekalongan is categorized as a safe city along with the stable criminal rates every year. In fact, security officers who specifically protect tourist sites have not been optimized. There tourism agency has cooperated with the authorities to keep the security during certain activities only. For the major events, including the Jlamprang Culture Festival and Batik Nusantara Exhibition, the tourism agent cooperates with the police officers to keep the event's security.

The disturbing issue in Pekalongan tourism is the tidal flood. Tidal floods is destructive for infrastructure and disrupt travel comfort. However, the government has an alternatives to overcome these problems, to save the existing tourist destinations. The local government obtained financial support from the provincial government to overcome the tidal flood by installing piles around the north coast. The such flood has damaged the existing tourist infrastructure around the coast, such as roads, toilets, parks, and sanitation. Whereas to achieve good halal tourism, this problem must be immediately solved.

\section{Service}

Lodging and restaurants are two significant aspects in tourism. Pekalongan has 3 shariabased hotels and the number still needs to be increased. Halal restaurants providing halal food are quite easy to find in Pekalongan, because the major population is muslim. Unfortunately, authorized institutions have not issued halal certificate for these culinary businesses. The city government has not initiated to ask for halal certificates from the culinary entrepreneurs. Regarding the completeness of accommodation, the numbers of sharia-based hotels need to be increased. On the other side, the worship places and facilities supporting halal tourism are sufficient, although they need improvement of the quality. It is an excellent action that the Tourism Department completes the religious facilities at tourist destinations through the Specific Allocation Fund (Dana Alokasi Khusus, DAK).

The aspects of developing of halal tourism in Pekalongan has already existed yet the conditions and numbers need to be increased and completed.Satriana\& Faridah [6] stated that Indonesia has a great opportunity to develop halal tourism. This is supported by the increasing number of Muslim tourists who travel to this country. This great opportunity is also achieved by Pekalongan City. The challenges of developing halal tourism faced by Pekalongan City are similar with Banjarmasin's [24]. The realizing process of halal tourism cannot immediately develop unless a genuine effort by all parties. This condition is different with Russia, where halal tourism develops in line with the increasing number of Muslims in the country [1]. 


\section{Conclusion}

Pekalongan has complete tourist destinations and supporting facilities which can be used as a capital for the development of halal tourism. In order to realize such tourism, the city needs culture, history, community conditions, and creativity to be the main foundation. Various tourism, including culture, shopping, religion, nature, events, and culinary are eligible to be tourist destinations. Therefore, the support of the city government to realize it needs to be optimized. Educational tourism of batik preservation needs to be managed more seriously as the consequence of its most potential attraction for the foreigners in the future. Moreover, Pekalongan has been known as the world's creative city. In order to become a halal tourism destination, such as other successful places, the Pekalongan must provide adequate supporting facilities and ensure the halal tourism ecosystem.

Pekalongan City needs to establish cooperation with various parties. First, establishing cooperation with local governments to develop halal tourism program. This strengthening effort is influential for not marketable area to realize it into halal tourism destination independently. The city government cooperates with universities to conduct halal tourism development research, the other institutions e.g. MUI to guarantee halal products, to conduct halal tourism education to tourism actors and the public.

\section{References}

[1] Gabdrakhmanov at al., "Problems of Development of Halal Tourism in Russia," $J$. Organ. Cult. Commun. Confl., vol. 20, no. 2, pp. 88-94, 2016.

[2] O. Chanin, P. Sriprasert, H. A. Rahman, and M. S. Don, "Guidelines on Halal Tourism Management in the Andaman Sea Coast of Thailand," J. Econ. Bus. Manag., vol. 3, no. 8, pp. 791-794, 2015.

[3] Abdul Waha N. Mohd Shahwahid F. \& Ab. Hamid N. 'Adha., "Issues, Challegnes and Strengths of the Halal Industry in Singapore: MUIS's Experience," in Proceeding of the 2nd International Conference on Economics \& Banking 2016 (2nd ICEB), 2016.

[4] I. Rosad, "Menuju Wisata Halal Jateng." .

[5] Mastercard-Crescentrating, "Global Muslim Travel Index 2019," 2019.

[6] E. D. Satriana and H. D. Faridah, "HALAL TOURISM: DEVELOPMENT, CHANCE AND CHALlenge," J. Halal Prod. Res., vol. 1, no. 2, p. 32, Dec. 2018.

[7] M. M. Battour, M. N. Ismail, and M. Battor, "Toward a Halal Tourism Market," Tour. Anal., vol. 15, no. 4, pp. 461-470, 2010.

[8] S. Chookaew, O. chanin, J. Charatarawat, P. Sriprasert, and S. Nimpaya, "Increasing Halal Tourism Potential at Andaman Gulf in Thailand for Muslim Country," J. Econ. Bus. Manag., vol. 3, no. 7, pp. 739-741, 2015.

[9] A. Jaelani, "Halal Tourism Industry in Indonesia: Potential and Prospects," SSRN Electron. J., 2017.

[10] "Inilah 6 sebutan nama lain Kota Pekalongan," 2019. .

[11] "Kota Pekalongan," 2019. .

[12] A. R. Subarkah, "Potensi dan Prospek Wisata Halal Dalam Meningkatkan Ekonomi Daerah (Studi Kasus: Nusa Tenggara Barat)," Sospol J. Sos. Polit., vol. 4, no. 2, pp. 49-72, 2018.

[13] “Cnbc Indonesia," 2019. .

[14] R. A. Kusumanto, "Wakaf Produktif. In Al-A'raf,” J. Pemikir. Islam dan Filsafat, vol. 
$12,2019$.

[15] J. C. Henderson, "Sharia-compliant hotels," Tour. Hosp. Res., vol. 10, no. 3, pp. 246254, Jun. 2010.

[16] B. N. Saad, H. E., \& Ali, "Sharia-compliant hotels in Egypt: Concept and chanllenges," Adv. Hosp. Tour. Res., vol. 2, no. 1, pp. 1-15, 2014.

[17] GMTI, "Global muslim travel index." 2019.

[18] Crewell J. W., "Chapter One-Selection Of Research Design," in Research design: Qualitative, Quantitative, and Mixed Methods Approaches, 3rd ed., SAGE publication, 2009.

[19] Yin R. K, Case Study Research: Design and Methods. Applied Social Research Methods Series, 2. Thousand Oaks. CA: Sage Publications, 1994.

[20] G. Payne and J. Payne, Key Concepts in Social Research. 1 Oliver's Yard, 55 City Road, London England EC1Y 1SP United Kingdom: SAGE Publications, Ltd, 2004.

[21] "Touris Pekalongan," 2019. .

[22] F. Rahmiati, N. A. Othman, and M. A. P. Sunanti, "MUSLIM TOURIST SATISFACTION OF HALAL TOURISM IN LOMBOK," J. SYARIKAH J. Ekon. Islam, vol. 4, no. 2, p. 122, Jan. 2019.

[23] S. M. Isa, P. N. Chin, and N. U. Mohammad, "Muslim tourist perceived value: a study on Malaysia Halal tourism," J. Islam. Mark., vol. 9, no. 2, pp. 402-420, Jun. 2018.

[24] M. Arif Budiman, "Opportunity and Threat of Developing Halal Tourism Destinations: A Case of Banjarmasin, Indonesia," Int. J. Econ. Behav. Organ., vol. 7, no. 1, p. $7,2019$. 